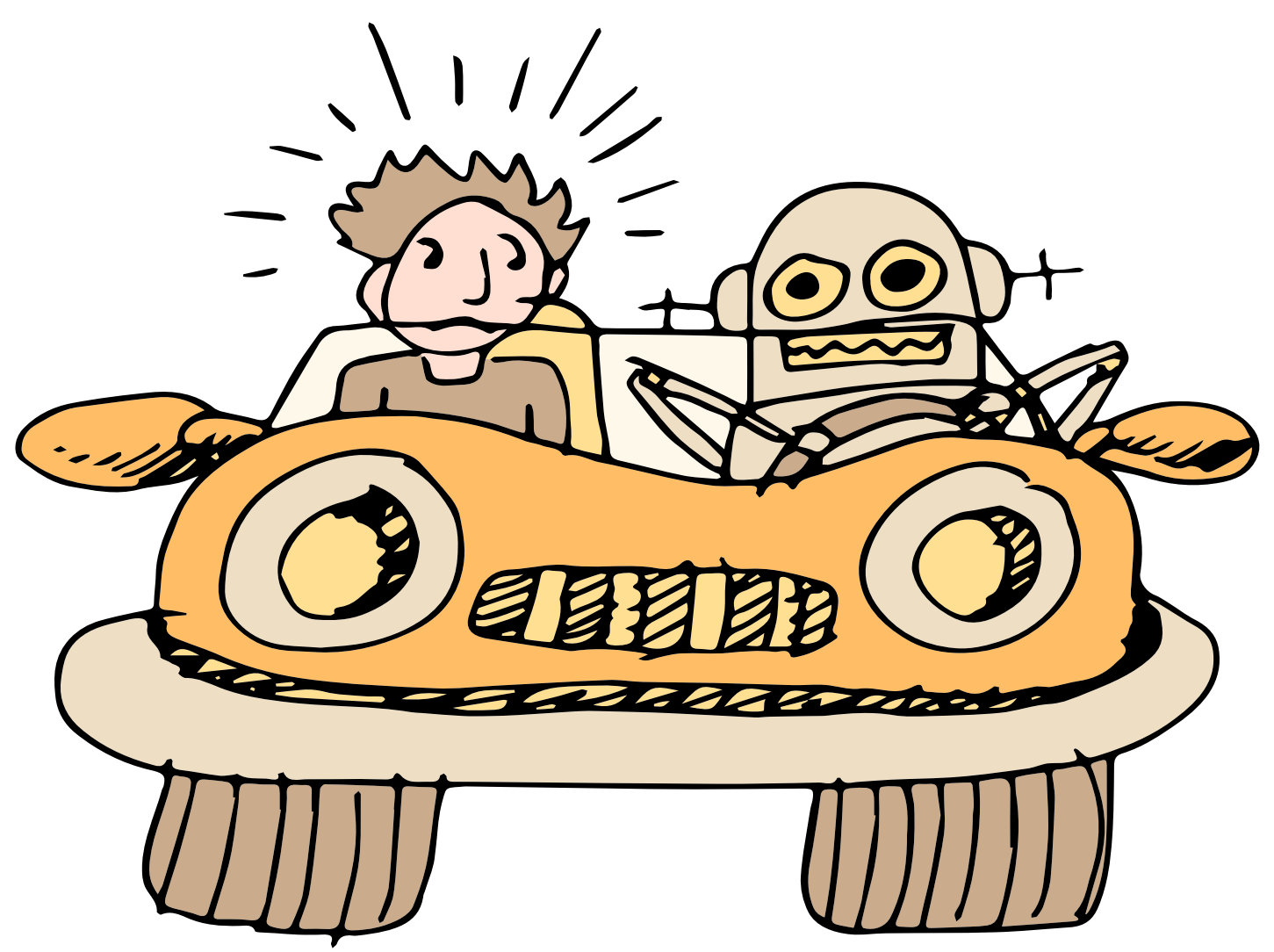

\title{
På tide å slå av autopiloten?
}

\section{Av Rose Desiree Kristensen}

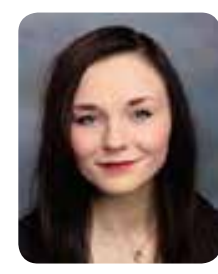

FOR SJU ÅR SIDEN var jeg så langt nede at jeg onsket å ta mitt eget liv. Gjennom Dialektisk atferdsterapi (DBT) lærte jeg meg mange ferdigheter som var avgiørende for at jeg klarte meg giennom den tunge tiden. Behandlingen fungerte spesielt godt for meg da denne behandlingen la vekt på å endre tankemonster (kognitiv atferdsterapi), trening i dialektisk tankegang og oppmerksomhetstrening (mindfulness). Noe som også var avgiørende for at det gikk så bra med meg, var at jeg søkte tilflukt hos en tante i helgene. Det som var spesielt med disse helgene var at jeg «slo av» tilgiengeligheten, både på mobilen og på sosiale medier. Venner og bekjente fikk ikke vite hvor jeg var og kunne ikke kontakte meg. Jeg trengte ikke å forholde meg til noen. Vi koste oss med film, musikk og bøker og så ikke på klokken. Vi levde i nået, uten å forholde oss til verden utenfor.

Når jeg ser tilbake på disse «offline-helgene», har jeg ofte tenkt på hvor mye man kan gå glipp av på grunn av mobilog internettbruk. Jeg har flere ganger opplevd å gå glipp av fantastiske øyeblikk fordi jeg fomler etter iPhonen for å ta et

Noe jeg oppdaget etter offline-helgene, var at «presset» utenfra minsket bilde. Men også de gangene jeg rekker å ta fram kamera i tide, får jeg ofte følelsen av å gå glipp av noe. Jeg føler meg distansert fra hendelsen når jeg ser det «innrammet» giennom kameralinsen, og i ettertid er det akkurat som om jeg ikke har vært tilstede da bildet ble tatt. Det er flott å ha noe å se tilbake på, men ofte blir jeg så opptatt av å dokumentere alt, at jeg glemmer å være oppmerksom på det som er akkurat nå.

I DBT-behandlingen lærte jeg mye om å være tilstede i nået, og å se at man har et valg i stedet for å være fanget $\mathrm{i}$ gamle vaner. Når man har klart å slå av autopiloten og ser 
at man kan ta et valg, enten valget er å fortsette slik som før eller å giøre en forandring, er det lettere å være tilstede i nået og å virkelig oppleve øyeblikkene. Jeg kan være tilstede i hverdagens små og store gleder, men jeg kan også noen ganger velge å «koble ut» ved hjelp av internett og elektroniske duppeditter.

Noe annet jeg oppdaget etter offline-helgene, var at «presset» utenfra minsket. Jeg tror mange av oss som bruker sosiale medier, leser aviser eller blogger opplever et slags press, uavhengig av hvordan vi i utgangspunktet føler oss. Det blir en slags konkurranse om å ha flest likes eller følgere, og det er lett å føle seg mislykket dersom man ikke får så mange. De fleste deler bilder og statusoppdateringer om sine "perfekte liv», men svært lite om det som ligger bak fasaden. Det blir som å kun male forsiden av huset, baksiden av huset kan være giennområttent, men ingen ser det.

Når man ikke klarer å leve opp til alle forventningene rundt seg, og det virker som om alle andre klarer det, er det ikke rart at mange sliter med depresion. «Hvorfor skal ikke jeg klare det, når alle andre klarer det?» er et av spørsmålene jeg har stilt meg selv når jeg ikke har klart å holde alle ballene i luften samtidig.

Likevel er det svært vanskelig å leve offline i dag. Jeg får ofte kritikk fra venner og familie fordi jeg svarer så sjeldent både på sosiale medier og på telefon, noen har også blitt forbannet fordi de har prøvd å få tak i meg i dagevis. Mange synes nok at jeg er egoistisk, og det er en måte å se det på, men det er så utrolig viktig for meg å selv kunne velge når jeg skal være tilgiengelig. Kanskje hadde det vært lettere om jeg ikke hadde noen mobiltelefon eller konto på sosiale medier, men jeg vil gierne ha muligheten til å bruke disse slik jeg selv onsker, ikke slik andre forventer. Grunnen til at jeg for noen år siden opprettet en Facebook-konto var fordi jeg begynte å føle meg utenfor. Jeg fikk ikke informasjon om konserter jeg selv skulle spille på, da flere av arrangørene bare ga beskjed om oppdrag via Facebook. Mange av mine venner og bekjente sendte bare invitasjoner til arrangementer giennom Facebook, og disse gikk jeg som oftest glipp av hvis ingen nevnte dem for meg.

For meg er det nok å vite at jeg når som helst kan slette kontoene på sosiale medier hvis det skulle bli for mye, det er valget som er viktig for meg. 